\title{
RNF130 wt Allele
}

National Cancer Institute

\section{Source}

National Cancer Institute. RNF130 wt Allele. NCI Thesaurus. Code C111932.

Human RNF130 wild-type allele is located in the vicinity of 5q35.3 and is approximately $153 \mathrm{~kb}$ in length. This allele, which encodes E3 ubiquitin-protein ligase RNF130 protein, plays a role in protein ubiquitylation. A fusion of this gene and the BRAF gene may be associated with pilocytic astrocytoma. 